\title{
PERBANDINGAN METODE RT-PCR DAN TES RAPID ANTIBODI UNTUK DETEKSI COVID-19
}

\author{
Anita Suswanti Agustina ${ }^{1}$, Rizana Fajrunni’mah ${ }^{2 凶}$ \\ ${ }^{1,2}$ Jurusan Teknologi Laboratorium Medis Poltekkes Kemenkes Jakarta III
}

\section{ARTICLE INFO \\ Article history}

Submitted : 2020-09-30

Revised : 2020-10-19

Accepted : 2020-10-25

\section{Keywords:}

COVID-19

SARS-CoV-2

RT-PCR

Rapid test antibody

\section{Kata Kunci:}

COVID-19

SARS-CoV-2

$R T$-PCR

Tes rapid antibodi

\begin{abstract}
COVID-19 is caused by SARS-CoV-2, which can spread rapidly from human to human. There are several laboratory tests to detect COVID-19, including the Reverse Transcription-Polymerase Chain Reaction (RT-PCR) method and a rapid test antibody test to detect antibody reactions to SARS-CoV-2. The type of research used is library research. We conducted library research of information to summarize knowledge about the pros and cons of RT-PCR and rapid test antibody testing to detect COVID-19. Research materials have been collected from various journals, books, and guidelines, in line with the research topic, to obtain 24 library sources. The results of the literature study indicate that the target genes that can be used to detect COVID-19 RT-PCR methods include the N, E, RdRp, and ORF1a/b genes. The sensitivity of rapid antibody tests is known to range from $68-89 \%$, while the specificity of rapid antibody tests ranges from $91-100 \%$. RT-PCR has the advantage of being able to detect lowconcentration antigens, but RT-PCR has weaknesses such as requiring expensive equipment and inspection fees, specially trained laboratory personnel, long working time, and high risk of exposure. Rapid antibody testing has advantages, including ease of sampling, lower testing costs, reduced risk of exposure to officers, does not require special equipment and space, but has the potential for cross-reactivity with other coronaviruses. Both the RT-PCR and rapid test antibody have their respective advantages and disadvantages. The results of the rapid antibody test are qualitative, so any reactive results should be confirmed by PCR. Antibody rapid test accompanied by RT-PCR is taken into consideration to show exposure to infection and improve the diagnostic detection of COVID-19. The results of this literature study are expected to be continued as a basis for further research on RT-PCR examination and antibody rapid test for COVID-19 detection in Indonesia, accompanied by information on onset time and time-testing with a large sample of research.

Penyakit COVID-19 disebabkan oleh SARS-CoV-2, dapat menyebar dari manusia ke manusia dengan cepat. Terdapat beberapa pemeriksaan laboratorium untuk mendeteksi COVID-19 di antaranya metode Reverse Transcription-Polymerase Chain Reaction (RT-PCR) dan pemeriksaan rapid test antibody untuk deteksi respons antibodi terhadap SARS-CoV-2. Jenis penelitian yang digunakan adalah studi kepustakaan (library research). Dalam studi ini menyediakan informasi mengenai kelebihan dan kekurangan RT-PCR dan rapid test antibody untuk deteksi COVID-19. Bahan penelitian dikumpulkan dari berbagai jurnal, buku, dan pedoman yang sesuai dengan topik penelitian sehingga didapatkan 24 sumber pustaka. Dari hasil studi literatur diketahui bahwa target gen yang dapat digunakan untuk deteksi COVID-19 metode RT-PCR antara lain gen N, E, RdRp, dan ORF1a/b. Sensitivitas rapid test antibody diketahui berkisar $68-89 \%$, sedangkan spesifisitas rapid test antibody berkisar $91-100 \%$. Metode RT-PCR memiliki keunggulan yaitu mampu mendeteksi antigen dengan konsentrasi yang rendah, namun RT-PCR memiliki kekurangan antara lain memerlukan peralatan dan biaya pemeriksaan yang mahal, petugas laboratorium dengan keahlian khusus, waktu pengerjaan yang cukup lama, serta risiko paparan yang tinggi. Pemeriksaan rapid test antibody memiliki kelebihan di antaranya kemudahan dalam pengerjaan sampel, biaya pemeriksaan lebih murah, mengurangi kemungkinan risiko paparan kepada petugas, tidak membutuhkan peralatan dan ruangan khusus, namun memiliki kekurangan kemungkinan adanya cross reactivity dengan corona virus lainnya. Baik metode RT-PCR maupun rapid test antibody memiliki kelebihan dan kekurangan masing-masing. Hasil rapid test antibody bersifat kualitatif, sehingga jika ditemukan hasil reaktif harus dikonfirmasi dengan pemeriksaan PCR. Pemeriksaan rapid test antibody disertai dengan RT-PCR dijadikan pertimbangan untuk menunjukkan paparan infeksi dan meningkatkan diagnostik deteksi COVID-19. Hasil studi literatur ini diharapkan bisa dilanjutkan sebagai dasar penelitian lebih lanjut pemeriksaan RT-PCR dan rapid test antibody untuk deteksi COVID-19 di Indonesia, disertai informasi waktu onset dan waktu pemeriksaan dengan sampel penelitian dalam jumlah besar.
\end{abstract}


Corresponding Author:

Rizana Fajrunni'mah

Jurusan Teknologi Laboratorium Medis Poltekkes Kemenkes Jakarta

Telp. 081325600090

Email: rie.ners@gmail.com

\section{PENDAHULUAN}

Penyakit COVID-19 pertama kali dilaporkan pada akhir Desember 2019 di Wuhan, China. World Health Organization (WHO) telah mengumumkan penyakit COVID19 sebagai pandemi yang sudah menyebar di 216 negara. Penyakit COVID-19 disebabkan oleh virus Severe Acute Respiratory Syndrome Coronavirus-2 (SARS-CoV-2) yang berbentuk bulat berdiameter $60-200 \mathrm{~nm}$ dengan banyak paku pada kapsid virus, dan tergolong ke dalam virus RNA untai tunggal $(26-32 \mathrm{~kb})$ (Bai, Cai, and Zhang, 2020). Penyakit ini menular ke antar manusia melalui percikan (droplet) dari hidung atau mulut, yang dikeluarkan ketika orang dengan COVID-19 batuk, bersin, atau berbicara (World Health Organization, 2020c). WHO memperkirakan SARS-CoV-2 memiliki reproductive number (R0) yang cukup tinggi (R0: 1.4-2.5) dibandingkan SARS-CoV (R0: 2-5) dan MERS-CoV (R0: <1) (Chen, 2020).

WHO merekomendasikan metode Reverse Transcription-Polymerase Chain Reaction (RT-PCR) sebagai gold standard diagnosis infeksi SARS-CoV-2 (World Health Organization, 2020b). Metode RT-PCR berfungsi mendeteksi adanya virus dalam tubuh pasien melalui reaksi rantai polimerase dengan primer atau probe yang khusus menargetkan genom SARS-CoV-2, sehingga jumlah cDNA SARS-CoV-2 dalam spesimen pasien dapat dihitung (Bai, Cai, and Zhang, 2020). Respons antibodi manusia untuk melawan virus pada awal infeksi dapat digunakan untuk mendukung diagnosis infeksi virus. Deteksi antibodi IgM bisa mengindikasi adanya pajanan baru (recent exposure) SARS-CoV-2, sedangkan deteksi antibodi $\mathrm{IgG}$ mengindikasi pajanan virus yang sudah lama (Li et al., 2020). Salah satu metode yang dapat digunakan untuk mengetahui adanya antibodi di dalam tubuh adalah rapid test antibody. Rapid test antibody menggunakan prinsip lateral flow assay, yang mampu mendeteksi antibodi dalam waktu 5-30 menit, dan proses pemeriksaannya tidak membutuhkan peralatan dan kemampuan khusus (Bai et al., 2020; Koczula \& Gallotta, 2016).
Food and Drug Administration (FDA) Amerika Serikat menyarankan penggunaan deteksi antibodi untuk membantu mengidentifikasi orang-orang yang mungkin terpapar virus SARS-CoV-2 atau telah pulih dari infeksi COVID-19. WHO menyampaikan deteksi antibodi digunakan untuk surveilans penyakit dan penelitian epidemiologi (World Health Organization, 2020a). Di Indonesia pemeriksaan rapid test antibody digunakan sebagai pemeriksaan skrining adanya antibodi terhadap COVID-19 misalnya pada pelaku perjalanan lintas batas, dan penguatan pelacakan kontak seperti di lapas, pondok pesantren, dll. Sementara pemeriksaan RT-PCR yang menggunakan sampel swab orofaring, nasofaring, atau sputum dijadikan pemeriksaan konfirmasi adanya SARS-CoV-2 di dalam tubuh. Studi literatur yang membandingkan kedua metode ini masih terbatas, oleh karena itu peneliti tertarik untuk membandingkan metode Reverse Transcription-Polymerase Chain Reaction (RT-PCR) dan rapid test antibody untuk deteksi COVID-19 melalui studi literatur.

\section{METODE}

Pencarian literatur dilakukan dengan menelusuri hasil publikasi ilmiah dalam sepuluh tahun terakhir (2010-2020) pada database Elsevier, Google Scholar, medRxiv, bioRxiv dan Pubmed. Kata kunci yang digunakan dalam pencarian literatur antara lain serology test, Reverse TranscriptionPolymerase Chain Reaction (RT-PCR), SARSCoV-2, dan COVID-19. Data yang diperoleh diolah menjadi artikel yang berbentuk review deskriptif.

\section{HASIL PENELITIAN}

Hasil studi literatur mengenai target gen yang digunakan untuk deteksi COVID-19, dapat dilihat pada Tabel 1 di bawah ini. Berbagai target gen sebagai primer sesuai dengan protokol pemeriksaan RT-PCR yang digunakan di berbagai negara saat ini antara lain gen N, E, RdRp, ORF1ab dan ORF1b menunjukkan limit deteksi (LoD) bervariasi yang ditunjukkan pada Tabel 1. 
Tabel 1. Target Gen (Primer) yang Digunakan untuk Deteksi COVID-19

\begin{tabular}{|c|c|c|c|}
\hline No & $\begin{array}{l}\text { Peneliti/ } \\
\text { Institusi }\end{array}$ & Primer ID & Hasil Penelitian \\
\hline 1 & $\begin{array}{l}\text { Corman et al. } \\
\quad(2020)\end{array}$ & $\begin{array}{l}\text { RdRp } \\
\text { Gen E } \\
\text { Gen N }\end{array}$ & $\begin{array}{l}\text { Limit deteksi } \\
\text { RdRp }=3,6 \text { salinan/reaksi } \\
\text { Gen } E=3,9 \text { salinan/reaksi } \\
\text { Gen N kurang sensitif } \\
\end{array}$ \\
\hline 2 & CDC China & $\begin{array}{l}\text { ORF1ab } \\
\text { Gen E } \\
\text { Gen N }\end{array}$ & $\begin{array}{l}\text { Limit deteksi } \\
\text { ORF1ab }=203 \text { salinan/reaksi } \\
\text { Gen } \mathrm{E}=664 \text { salinan/reaksi } \\
\text { Gen } \mathrm{N}=667 \text { salinan } / \text { reaksi }\end{array}$ \\
\hline 3 & $\begin{array}{l}\text { Charité- } \\
\text { Jerman }\end{array}$ & $\begin{array}{l}\text { RdRp_SARSr } \\
\text { E_Sarbeco }\end{array}$ & $\begin{array}{l}\text { Limit deteksi } \\
\text { RdRp_SARSr }=3,8 \text { salinan/ reaksi } \\
\text { E_Sarbeco }=5,2 \text { salinan/reaksi }\end{array}$ \\
\hline 4 & CDC USA & $\begin{array}{l}\text { 2019-nCoV_N1 } \\
\text { 2019-nCOV_N2 } \\
\text { 2019-nCOV_N3 }\end{array}$ & $\begin{array}{l}95 \% \text { sampel mengandung } 10^{0,5} \text { salinan } / \mu \mathrm{L} \\
\text { menggunakan alat otomatisasi ekstraksi } \\
\text { RNA dan } 10^{0} \text { salinan } / \mu \mathrm{L} \text { menggunakan } \\
\text { metode manual ekstraksi RNA. }\end{array}$ \\
\hline 5 & $\begin{array}{l}\text { National } \\
\text { Istitute of } \\
\text { Health- } \\
\text { Thailand }\end{array}$ & $\mathrm{N}$ & $\begin{array}{l}\text { Gen N dengan } C t \text { value hingga } 38,12 \text {, } \\
\text { sebanding dengan } 15 \text { salinan/reaksi. }\end{array}$ \\
\hline 6 & $\begin{array}{l}\text { Hong Kong } \\
\text { University- } \\
\text { Hong Kong }\end{array}$ & $\begin{array}{c}\text { Gen N } \\
\text { ORF1b-nsp14 }\end{array}$ & $\begin{array}{l}\text { Gen } \mathrm{N} \text { dengan } C t \text { value hingga } 35,43 \\
\text { menunjukkan hasil positif sebanding } \\
\text { dengan } 15 \text { salinan/reaksi. } \\
\text { Gen ORF1b dengan } C t \text { value hingga } 38,97 \\
\text { menunjukkan hasil positif sebanding } \\
\text { dengan } 1,5 \text { salinan/reaksi. }\end{array}$ \\
\hline
\end{tabular}

Berdasarkan hasil studi literatur yang tercantum pada Tabel 2 diketahui bahwa penelitian yang meneliti 1070 spesimen yang dikumpulkan dari 205 pasien, menemukan bahwa spesimen cairan bronchoalveolar lavage (BAL) untuk pemeriksaan PCR menunjukkan hasil positif tertinggi (14 dari 15; 93\%), diikuti oleh sputum, swab nasal, biopsi fibrobronchoscope brush, dan swab faring. Tidak satu pun dari 72 spesimen urin menunjukkan hasil positif (Wang et al., 2020).

Tabel 2. Hasil Positif Berbagai Spesimen untuk Pemeriksaan RT-PCR

\begin{tabular}{lcc}
\hline \multicolumn{1}{c}{ Jenis Spesimen } & Jumlah Sampel & Hasil Positif (\%) \\
\hline Cairan bronchoalveolar lavage & 15 & $14(93)$ \\
Biopsi fibrobronchoscope brush & 13 & $6(46)$ \\
Sputum & 104 & $75(72)$ \\
Swab nasofaring & 8 & $5(63)$ \\
Swab orofaring & 398 & $126(32)$ \\
Feses & 153 & $44(29)$ \\
Darah & 307 & $3(1)$ \\
Urin & 72 & 0 \\
\hline
\end{tabular}

Berdasarkan hasil studi literatur Pan et al. (2020) yang tercantum pada Tabel 3 diketahui bahwa baik antibodi IgM maupun IgG sudah muncul terbentuk sejak hari ke 1-7 setelah onset, antibodi $\operatorname{IgM}$ mencapai kemampuan deteksi tertinggi pada hari ke 8-14 
setelah onset yakni $78,6 \%$, sedangkan antibodi IgG paling baik dideteksi pada hari ke-15 sesudah onset sebesar 96,80\%. Kedua antibodi
IgM dan IgG terdeteksi pada pasien COVID-19 sesudah hari ke-15 setelah onset.

Tabel 3. Uji IgM dan IgG Berdasarkan Waktu Sesudah Muncul Gejala pada Terduga COVID-19

\begin{tabular}{cccccc}
\hline Jenis Pemeriksaan & Waktu Tes & $\begin{array}{c}\text { Jumlah } \\
\text { Sampel }\end{array}$ & $\begin{array}{c}\text { IgM Reaktif } \\
(\mathbf{\%})\end{array}$ & $\begin{array}{c}\text { IgG Reaktif } \\
(\boldsymbol{\%})\end{array}$ & $\begin{array}{c}\text { IgM Reaktif } \\
\text { dan IgG } \\
\text { Reaktif (\%) }\end{array}$ \\
\hline Uji strip IgM atau IgG & Hari ke 1-7 & 27 & $3(11,1 \%)$ & $1(3,7 \%)$ & $3(11,1 \%)$ \\
pada pasien yang & Hari ke 8-14 & 28 & $22(78,6 \%)$ & $16(57,1 \%)$ & $26(92,9 \%)$ \\
terkonfirmasi RT-PCR & Hari ke $\geq 15$ & 31 & $48(74,2 \%)$ & $30(96,8 \%)$ & $30(98,6 \%)$ \\
Uji strip IgM atau IgG & Hari ke 1-7 & 9 & $2(22,2 \%)$ & $4(44,4 \%)$ & $4(44,4 \%)$ \\
pada pasien dengan & Hari ke 8-14 & 6 & $2(33,3 \%)$ & $4(66,7 \%)$ & $5(83,3 \%)$ \\
RT-PCR negatif & Hari ke $\geq 15$ & 7 & $4(57,1 \%)$ & $5(71,4 \%)$ & $5(71,4 \%)$ \\
\hline
\end{tabular}

Tabel 4. Hasil Pemeriksaan RT-PCR dan Tes Rapid Antibodi

\begin{tabular}{|c|c|c|c|c|c|c|}
\hline \multirow[b]{2}{*}{ No } & \multirow[b]{2}{*}{ Peneliti } & \multirow[b]{2}{*}{$\begin{array}{c}\text { Alat Pemeriksaan } \\
\text { Antibodi }\end{array}$} & \multirow{2}{*}{$\begin{array}{c}\text { Hasil } \\
\text { Pemeriksaan } \\
\text { Antibodi }\end{array}$} & \multicolumn{2}{|c|}{ Hasil Pemeriksaan PCR } & \multirow[b]{2}{*}{$P$ value } \\
\hline & & & & $\begin{array}{c}\text { PCR } \\
\text { Positif (n) }\end{array}$ & $\begin{array}{c}\text { PCR } \\
\text { Negatif (n) }\end{array}$ & \\
\hline \multirow{3}{*}{1} & \multirow{3}{*}{$\begin{array}{l}\text { Ying et } \\
\text { al. }(2020)\end{array}$} & \multirow{3}{*}{$\begin{array}{c}\text { SARS-CoV-2 } \\
\text { IgG/IgM antibody } \\
\text { test kit by a Chinese } \\
\text { biotechnology } \\
\text { company }\end{array}$} & $\begin{array}{l}\text { Antibodi reaktif } \\
\text { (n) }\end{array}$ & 77 & 8 & \multirow{3}{*}{$<0.001$} \\
\hline & & & $\begin{array}{c}\text { Antibodi non } \\
\text { reaktif (n) }\end{array}$ & 13 & 81 & \\
\hline & & & Total & 90 & 89 & \\
\hline \multirow{3}{*}{2} & \multirow{3}{*}{$\begin{array}{l}\text { Li et al. } \\
(2020)\end{array}$} & \multirow{3}{*}{$\begin{array}{c}\text { SARS-CoV-2 rapid } \\
\text { IgG-IgM } \\
\text { by Jiangsu } \\
\text { Medomics Medical } \\
\text { Technologies }\end{array}$} & $\begin{array}{l}\text { Antibodi reaktif } \\
\text { (n) }\end{array}$ & 352 & 12 & \multirow{3}{*}{ - } \\
\hline & & & $\begin{array}{c}\text { Antibodi non } \\
\text { reaktif (n) }\end{array}$ & 45 & 116 & \\
\hline & & & Total & 397 & 128 & \\
\hline \multirow{9}{*}{3} & \multirow{9}{*}{$\begin{array}{l}\text { Montesin } \\
\text { os et al. } \\
(2020)\end{array}$} & \multirow{3}{*}{$\begin{array}{l}\text { Novel Coronavirus } \\
(2019-\mathrm{n}-\mathrm{CoV}) \\
\text { antibody IgG/IgM } \\
\text { assay (Avioq) }\end{array}$} & $\begin{array}{l}\text { Antibodi reaktif } \\
\text { (n) }\end{array}$ & 88 & 3 & \multirow{3}{*}{-} \\
\hline & & & $\begin{array}{l}\text { Antibodi non } \\
\text { reaktif }(\mathrm{n})\end{array}$ & 40 & 69 & \\
\hline & & & Total & 128 & 72 & \\
\hline & & \multirow{3}{*}{$\begin{array}{l}\text { QuickZen COVID- } \\
19 \text { IgM/IgG Kit } \\
\text { (QuickZen) }\end{array}$} & $\begin{array}{l}\text { Antibodi reaktif } \\
\text { (n) }\end{array}$ & 91 & 0 & \multirow{3}{*}{-} \\
\hline & & & $\begin{array}{c}\text { Antibodi non } \\
\text { reaktif }(\mathrm{n})\end{array}$ & 37 & 72 & \\
\hline & & & Total & 128 & 72 & \\
\hline & & \multirow{3}{*}{$\begin{array}{c}\text { 2019-n-CoV } \\
\text { IgG/IgM rapid test } \\
\text { cassette (LaboOn } \\
\text { Time) }\end{array}$} & $\begin{array}{l}\text { Antibodi reaktif } \\
\text { (n) }\end{array}$ & 92 & 0 & \multirow{3}{*}{ - } \\
\hline & & & $\begin{array}{l}\text { Antibodi non } \\
\text { reaktif (n) }\end{array}$ & 36 & 72 & \\
\hline & & & Total & 128 & 72 & \\
\hline
\end{tabular}

Berdasarkan Tabel 4 diketahui hasil pemeriksaan rapid test antibody menggunakan kit yang berbeda menghasilkan sensitivitas dan spesifisitas, PPV, NPV dan akurasi yang berbeda pula. 
Penelitian Ying et al. (2020) yang meneliti 179 pasien, terdiri dari 90 pasien positif PCR dan 89 pasien negatif PCR. Rapid tes antibody memiliki sensitivitas sebesar $85,6 \%$ dan spesifisitas sebesar $91 \%$. Penelitian tersebut menginformasikan bahwa nilai positive predictive value (PPV) sebesar 90,5\%, dan negative predictive value (NPV) sebesar $86,1 \%$. Akurasi dari rapid test antibody sebesar 88,3\%. Efisiensi Kappa antara test kit $\mathrm{IgG} / \mathrm{IgM}$ dan RT-PCR adalah 0,75 (p < 0,001) (Tabel 4).

Penelitian yang dilakukan $\mathrm{Li}$ et al. (2020) bertujuan untuk mengetahui sensitivitas dan spesifisitas rapid test antibody IgM dan IgG menggunakan 397 pasien positif COVID19 dan 128 orang sehat yang dikumpulkan dari 8 rumah sakit dan laboratorium $\mathrm{CDC}$ di berbagai provinsi di China, menemukan bahwa sensitivitasnya $88,66 \%$ dan spesifitasnya
90,63\%. Penelitian tersebut juga menginformasikan bahwa nilai positive predictive value (PPV) sebesar 96,7\% dan negative predictive value (NPV) sebesar 72,0\%. Akurasi dari rapid test antibody adalah $89,1 \%$ (Tabel 4).

Hasil penelitian Montesinos et al. (2020) yang membandingkan tiga alat rapid test antibody berbeda dengan mengikutsertakan 128 sampel positif RT-PCR dan 72 sampel orang sehat sebagai kontrol negatif menunjukkan hasil yang berbeda pula. Sensitivitas dan spesifisitas kombinasi IgM dan IgG masing-masing berkisar $69-72 \%$, dan $96-100 \%$. Nilai positive predictive value (PPV) diketahui berkisar 96-100\%, dan negative predictive value (NPV) berkisar $63-67 \%$. Akurasi dari kombinasi IgM dan IgG juga bervariasi yakni $83-86 \%$ (Tabel $4)$.

Tabel 5. Perbandingan Metode RT-PCR dan Rapid Test Antibody

\begin{tabular}{|c|c|c|}
\hline & Deteksi RNA & Rapid Test Antibody \\
\hline Metode & $\begin{array}{c}\text { Reverse Transcription- } \\
\text { Polymerase Chain Reaction } \\
\text { (RT-PCR) }\end{array}$ & Lateral flow assay (LFA) \\
\hline Deteksi & RNA virus (antigen) & Antibodi (IgM, IgG) \\
\hline Sampel & $\begin{array}{c}\text { Swab orofaring/ nasofaring, } \\
\text { sputum, cairan BAL }\end{array}$ & Serum/plasma, whole blood \\
\hline $\begin{array}{c}\text { Batas deteksi } \\
\text { terendah }\end{array}$ & 0,5 salinan $/ \mu \mathrm{L}$ & $\geq 10$ salinan $/ \mu \mathrm{L}$ \\
\hline $\begin{array}{c}\text { Waktu pengerjaan } \\
\text { sampel }\end{array}$ & $2-3$ jam & $15-20$ menit \\
\hline $\begin{array}{c}\text { Kemampuan alat } \\
\text { mengerjakan sampel }\end{array}$ & Deteksi dalam jumlah besar & Deteksi satu per satu sampel \\
\hline Keahlian petugas & $\begin{array}{l}\text { Memerlukan keahlian } \\
\text { khusus (tinggi) }\end{array}$ & $\begin{array}{c}\text { Tidak memerlukan keahlian } \\
\text { khusus (tinggi) }\end{array}$ \\
\hline $\begin{array}{l}\text { Kebutuhan peralatan } \\
\text { dan ruangan }\end{array}$ & $\begin{array}{l}\text { Pengerjaan sampel } \\
\text { membutuhkan alat dan } \\
\text { ruangan laboratorium } \\
\text { khusus (minimal BSL-2) }\end{array}$ & $\begin{array}{l}\text { Pengerjaan sampel tidak } \\
\text { membutuhkan alat dan ruangan } \\
\text { khusus, dapat dilakukan di } \\
\text { fasilitas masyarakat seperti } \\
\text { stasiun, sekolah, pasar }\end{array}$ \\
\hline $\begin{array}{l}\text { Biaya peralatan dan } \\
\text { pemeriksaan }\end{array}$ & Mahal & $\begin{array}{c}\text { Lebih murah dibandingkan RT- } \\
\text { PCR }\end{array}$ \\
\hline $\begin{array}{l}\text { Risiko paparan } \\
\text { kepada petugas }\end{array}$ & Risiko tinggi & Risiko sedang \\
\hline
\end{tabular}

Secara keseluruhan metode RT-PCR dan rapid test antibody memiliki kelebihan dan kekurangan masing-masing. Berdasarkan Tabel 5, metode RT-PCR memiliki kemampuan deteksi dengan konsentrasi yang rendah sebesar
0,5 salinan/ $\mu \mathrm{L}$, sementara konsentrasi analit yang dibutuh-kan pada rapid test antibody agar hasilnya bisa dipercaya harus lebih tinggi dari 10 salinan $/ \mu \mathrm{L}$. 


\section{PEMBAHASAN}

Pemilihan primer dan probe yang tepat juga harus diperhatikan mengingat komponen ini bisa mempengaruhi akurasi diagnostik deteksi COVID-19 dengan metode PCR (Lippi, Simundic, \& Plebani, 2020). Penggunaan lebih dari satu target pada pemeriksaan RT-PCR yang terlihat pada Tabel 1, dapat meningkatkan spesifisitas tes. Sementara RT-PCR multiplex memungkinkan identifikasi virus dalam spesimen dengan viral load yang rendah. Viral load yang rendah dapat terjadi pada orang tanpa gejala, selama tahap awal atau akhir COVID19, atau dapat disebabkan proses pengumpulan spesimen yang tidak tepat (Leblanc et al., 2020).

Selain pemilihan primer dan probe, jenis sampel yang digunakan juga mempengaruhi kemampuan RT-PCR untuk mendeteksi COVID-19. Akibat dari jumlah ekspresi angiotensin-converting enzyme-2 (ACE2) sebagai reseptor masuknya sel SARSCoV-2 ke dalam tubuh yang lebih banyak diekspresikan di paru-paru dibandingkan saluran pernapasan atas, menyebabkan hasil deteksi di paru-paru lebih akurat namun risiko paparan akibat proses pengumpulan sampelnya pun lebih tinggi (Jahromi, Avazpour, Jahromi, \& Alavi, 2020).

Berdasarkan hasil penelitian Pan et al. (2020) yang tercantum pada Tabel 3, IgM dan IgG pertama kali terdeteksi pada pasien terkonfirmasi COVID-19 pada hari ke-4, deteksi adanya antibodi IgM yang terbentuk stabil bertahan sebesar $75 \%$ pada tahap menengah hingga akhir setelah onset, sementara deteksi antibodi IgG terus meningkat selama perkembangan penyakit. Hasil ini sesuai dengan penelitian Guo et al. (2020) yang menyatakan bahwa antibodi IgM dan IgA sebagai penanda infeksi akut rata-rata terdeteksi pada hari kelima (hari ke 3-6), sedangkan antibodi $\operatorname{IgG}$ muncul rata-rata pada hari ke-14 (10-18 hari). Studi sebelumnya yang dilakukan oleh Hou et al. (2020) juga menunjukkan hasil yang tidak berbeda bahwa IgM dihasilkan pada pasien COVID-19 dalam satu minggu setelah onset gejala, kemudian mencapai tingkat puncaknya pada 2-3 minggu, setelah itu levelnya menurun. Level IgG meningkat dengan cepat dan bertahan pada level tinggi selama 2 bulan.

Hasil negatif palsu pada rapid test antibody bisa disebabkan karena window period yang panjang, dan tidak diketahuinya secara pasti kapan pasien terinfeksi atau berapa lama pasien terinfeksi. Ketika antibodi belum terbentuk atau konsentrasi yang terbentuk masih rendah maupun antibodi sudah berkurang di dalam tubuh, kadarnya tidak bisa terdeteksi oleh alat (Bai et al., 2020; Li et al., 2020). Selain itu hasil negatif palsu rapid test antibody dapat terjadi pada pasien immunocompromised (gangguan pembentukan antibodi) yang terinfeksi COVID-19 (Triyani, Noormartany, \& Nilapsari, 2020). Terjadinya cross reactivity antibodi dengan berbagai virus lain (coronavirus, dengue virus) juga memungkinkan adanya hasil positif palsu. Studi cross reactivity yang diteliti Guo et al. (2020) menunjukkan adanya reaktivitas silang yang kuat antara plasma manusia positif-SARS-CoV dan SARSCoV-2. Hal ini bisa disebabkan karena kedua virus menggunakan reseptor yang sama, angiotensin-converting enzyme-2 (ACE2).

Keunggulan yang dimiliki metode RTPCR adalah kemampuan alatnya yang mampu memeriksa dalam jumlah banyak dalam satu waktu. Namun metode RT-PCR membutuhkan teknisi profesional yang mampu melakukan pemeriksaan RT-PCR dan menganalisis data dengan tepat, serta peralatan khusus karena proses pengerjaannya yang relatif lebih rumit (Bai et al., 2020). Pada metode RT-PCR, kesalahan pengerjaan yang tidak sesuai dengan prosedur dimulai dari pra analitik misalnya identifikasi sampel yang salah, proses pengambilan sampel yang tidak benar, kualitas spesimen yang buruk atau hanya mengandung sangat sedikit sampel, kondisi pengiriman dan penyimpanan sampel yang tidak akurat, kontaminasi sampel, adanya kesalahan pipetting selama persiapan sampel manual atau aliquot, menjadi penyebab kesalahan diagnostik. Pada tahap analitik adanya kontaminasi silang, pengujian di luar jendela diagnostik/fase infeksi, ketidaksesuaian primer dan probe, penggabungan nukleotida yang salah, serta penempelan pada target non spesifik sebagai risiko rekombinasi aktif dan mutasi memungkinkan adanya hasil negatif palsu (Lippi et al., 2020).

Dilihat dari aspek pengerjaan, rapid test antibody lebih unggul jika dibandingkan dengan metode RT-PCR karena mudah dilakukan dan menghemat waktu. Pemeriksaan rapid test antibody tidak memerlukan peralatan yang rumit dan khusus. Pengerjaannya pun relatif cepat, setiap pemeriksaan satu sampel hingga hasil bisa diinterpretasi hanya 
membutuhkan waktu 15-20 menit (Pan et al., 2020). Selain itu pemeriksaan ini juga bisa digunakan untuk pengujian massal yang bisa dilakukan di rumah sakit, klinik, laboratorium, di kawasan bisnis, sekolah, bandara, pelabuhan dan stasiun kereta api (Li et al., 2020). Tidak seperti pengerjaan RT-PCR yang membutuhkan laboratorium minimal dengan fasilitas BSL-2 (World Health Organization, 2020b). Penggunaan sampel berupa serum atau plasma darah yang bisa diambil melalui vena maupun jari tangan, juga mengurangi risiko paparan aerosol berupa batuk maupun bersin dari pasien kepada petugas laboratorium yang mungkin terjadi saat pengambilan sampel pada swab nasofaring atau orofaring (Li et al., 2020).

\section{KESIMPULAN DAN SARAN}

Metode RT-PCR memiliki batas deteksi konsentrasi analit yang lebih rendah dibandingkan rapid test antibody. Namun RTPCR memiliki kekurangan antara lain peralatan dan biaya pemeriksaan yang mahal, waktu pengerjaan yang cukup lama (2-3 jam), dan risiko paparan yang tinggi. Mengingat proses pengerjaan yang lebih kompleks maka diperlukan petugas laboratorium dengan keahlian khusus dan berkompeten untuk mengurangi kemungkinan kesalahan teknis. Rapid test antibody menyediakan kemudahan dalam proses pengerjaan sampel, biaya peralatan dan pemeriksaan yang lebih murah, tidak membutuhkan ruangan khusus, dapat digunakan untuk pemeriksaan massal, serta mengurangi kemungkinan risiko paparan kepada petugas. Kekurangan dari rapid test antibody yakni kemungkinan adanya cross reactivity dengan corona virus lainnya. Hasil pemeriksaan rapid test antibody yang reaktif tetap harus dikonfirmasi dengan tes PCR.

Adapun keterbatasan dalam studi literatur ini yaitu kemampuan peneliti dalam melakukan tinjauan secara sistematis dalam pengerjaan studi literatur, dan menginterpretasi hasil penelitian yang sudah ada. Selain itu pengembangan penelitian mengenai COVID-19 yang terus dilakukan memungkinkan adanya informasi baru yang mungkin belum didapatkan oleh peneliti.

\section{DAFTAR PUSTAKA}

Bai, H., Cai, X., \& Zhang, X. (2020). A comparison of PCR vs Immunoassay vs Crispr-Based test. OSF Preprints. https://doi.org/10.13581/j.cnki.rdm.2019.
04.007.

Chen, J. (2020). Pathogenicity and transmissibility of 2019-nCoV-A quick overview and comparison with other emerging viruses. Microbes and Infection, 22(2), 69-71. https://doi. org/10.1016/ j.micinf.2020.01.004.

Corman, V. M., Landt, O., Kaiser, M., Molenkamp, R., Meijer, A., Chu, D. K. W., ... Drosten, C. (2020). Detection of 2019 novel coronavirus (2019-nCoV) by real-time RT-PCR. Eurosurveillance, 25(3), 1-8. https://doi.org/10.2807/15607917.ES.2020.25.3.2000045.

Guo, L., Ren, L., Yang, S., Xiao, M., Chang, D., Yang, F., ... Wang, J. (2020). Profiling Early Humoral Response to Diagnose Novel Coronavirus Disease (COVID-19). Clinical Infectious Diseases: An Official Publication of the Infectious Diseases Society of America, (Xx Xxxx), 1-8. https://doi.org/10.1093/ cid/ciaa310.

Hou, H., Wang, T., Zhang, B., Luo, Y., Mao, L., Wang, F., ... Sun, Z. (2020). Detection of $\operatorname{IgM}$ and $\operatorname{IgG}$ antibodies in patients with coronavirus disease 2019 . Clinical \& Translational Immunology, 9(5), 1-8. https://doi. org/ 10.1002/cti2.1136.

Jahromi, R., Avazpour, A., Jahromi, M., \& Alavi, J. (2020). COVID-19 with Positive Bronchoalveolar Lavage Fluid (BALF) But Negative Nasopharyngeal and Oropharyngeal Swabs: Case Report and Insights. Preprints, 4(June), 9-13. https://doi.org/10.20944/PREPRINTS202 006.0113.V1.

Koczula, K. M., \& Gallotta, A. (2016). Lateral flow assays. Essays in Biochemistry, 60(1),111-120. https://doi.org/10.1042/ EBC20150012.

Leblanc, J. J., Gubbay, J. B., Li, Y., Needle, R., Arneson, S. R., Marcino, D., ... Yu, Y. (2020). Real-time PCR-based SARSCoV-2 detection in Canadian laboratories. Journal of Clinical Virology, 128(10433). https://doi.org /10.1016/j.jcv.2020.104433.

Li, Z., Yi, Y., Luo, X., Xiong, N., Liu, Y., Li, S., ... Ye, F. (2020). Development and Clinical Application of A Rapid IgM-IgG Combined Antibody Test for SARSCoV-2 Infection Diagnosis. Journal of Medical Virology,0-1. https://doi.org/ 
10.1002/jmv. 25727.

Lippi, G., Simundic, A.-M., \& Plebani, M. (2020). Potential preanalytical and analytical vulnerabilities in the laboratory diagnosis of coronavirus disease 2019 (COVID-19). Clinical Chemistry and Laboratory Medicine (CCLM), (0). https://doi.org/10.1515/cclm-2020-0285.

Montesinos, I., Gruson, D., Kabamba, B., Dahma, H., Van den Wijngaert, S., Reza, S., ... Rodriguez-Villalobos, H. (2020). Evaluation of two automated and three rapid lateral flow immunoassays for the detection of anti-SARS-CoV-2 antibodies. Journal of Clinical Virology, 128(April), 104413.https://doi.org/ 10.1016/j.jcv.2020.104413.

Pan, Y., Li, X., Yang, G., Fan, J., Tang, Y., Zhao, J., ... Li, Y. (2020). Serological immunochromatographic approach in diagnosis with SARS-CoV-2 infected COVID-19 patients. Journal of Infection, (xxxx).https://doi.org/10.1016/j.jinf.2020 .03 .051 .

Triyani, Y., Noormartany, \& Nilapsari, R. (2020). COVID-19 dan Peran Pemeriksaan Laboratorium. In Bunga Rampai Artikel Penyakit Virus Korona (COVID-19) (pp. 45-61).

Wang, W., Xu, Y., Gao, R., Lu, R., Han, K., Wu, G., \& Tan, W. (2020). Detection of
SARS-CoV-2 in Different Types of Clinical Specimens. JAMA - Journal of the American Medical Association, 2324. https://doi.org/ 10.1001/ jama. 2020.3786.

World Health Organization. (2020a). Advice on the use of point-of-care immunodiagnostic tests for COVID-19. WHO - Scientific Brief, (April), 1-3. Retrieved from https://www.who.int/ newsroom/commentaries/ detail/adviceon-the-use- of-point- of-careimmunodiagnostic-tests-for-covid-19.

World Health Organization. (2020b). Laboratory testing for coronavirus disease (COVID-19) in suspected human cases. WHO - Interim Guidance, (19 March), 1-7.

World Health Organization. (2020c). Q\&A on coronaviruses (COVID-19). Retrieved from https://www.who.int/ emergencies/ diseases/ novel- coronavirus2019/ question-and-answers-hub/q-a-detail/q-acorona viruses.

Ying, L., Yue-ping, L., Bo, D., Feifei, R., Yue, W., Jinya, D., ... Theater, C. (2020). Diagnostic Indexes of a Rapid IgG/IgM Combined Antibody Test for SARSCoV-2. MedRxiv. https://doi.org/10.1101/ 2020.03.26.20044883. 